\title{
The economics of deleveraging: The aftermath of financialization
}

\author{
Thomas I. Palley*
}

\begin{abstract}
This paper provides a simple model of deleveraging that surfaces the contradictions inherent in neoliberal financialization and explains the pattern of US business cycles over the past thirty years. Deleveraging involves a two step correction. The first step is when a borrowing boom ends. The second step is when agents increase saving and re-pay debt. Borrowing accelerates economic activity as consumers spend. When borrowing stops, the economy slows. Moreover, the economy is further slowed by accumulated debt burdens. With deleveraging, households increase saving and re-pay debt which deepens the economic slowdown. Repayment reduces debt, helping economic activity eventually to recover.

JEL classifications: $E_{20}, E_{3} 0, E_{32}$

Keywords: deleveraging, debt, financialization
\end{abstract}

\section{Introduction}

After almost three decades of declining household saving rates and increasing consumer debt, the US economy has now entered a period of deleveraging marked by rising household saving rates and declining consumer credit. As shown in Table I, the household saving rate fell from IO.6 percent in I98I to I.2 percent in the first quarter of 2008, but has since been trending up, reaching as high as 5.4 percent in the second quarter of 2009. Table 2 shows that total outstanding consumer credit grew at an annual rate above 4 percent from 2004 to 2007 , and then collapsed abruptly in the third quarter of 2008 . In the fourth quarter of 2008 consumer credit growth turned negative and it was negative throughout 2009.

* New America Foundation, Washington DC.

Correspondence Address:

Thomas I. Palley, 1913 S Street NW, Washington, DC 20009, USA, e-mail: mail@thomaspalley.com.

Received, o6 January 2010, accepted o7 June 2010

(C) INTERVENTION 7 (2), 20IO, 40I-4I3 
Table I: Personal saving rate (PSR) as percent of personal income

\begin{tabular}{c|ccc}
\hline \hline Year & PSR (\%) & Year & PSR (\%) \\
\hline 1980 & 9.8 & $2008 . \mathrm{I}$ & 1.2 \\
1981 & 10.6 & $2008 . \mathrm{II}$ & 3.4 \\
1991 & 7.0 & $2008 . \mathrm{III}$ & 2.2 \\
2001 & 2.7 & $2008 . \mathrm{IV}$ & 3.8 \\
2007 & 1.7 & $2009 . \mathrm{I}$ & 3.7 \\
2008 & 2.7 & $2009 . \mathrm{II}$ & 5.4 \\
2009 & 4.3 & $2009 . \mathrm{III}$ & 4.5 \\
& & $2009 . \mathrm{IV}$ & 3.9 \\
\hline
\end{tabular}

Source: Bureau of Economic Analysis

Table 2: Annualized growth of consumer credit (\%)

\begin{tabular}{cccccccccccc}
\hline 2004 & 2005 & 2006 & 2007 & $\begin{array}{c}2008 \\
-\mathrm{q}^{1}\end{array}$ & $\begin{array}{c}2008 \\
-\mathrm{q}^{2}\end{array}$ & $\begin{array}{c}2008 \\
-\mathrm{q}^{3}\end{array}$ & $\begin{array}{c}2008 \\
-\mathrm{q}^{4}\end{array}$ & $\begin{array}{c}2009 \\
-\mathrm{q}^{1}\end{array}$ & $\begin{array}{c}2009 \\
-\mathrm{q}^{2}\end{array}$ & $\begin{array}{c}2009 \\
-\mathrm{q}^{3}\end{array}$ & $\begin{array}{c}2009 \\
-\mathrm{q}^{4}\end{array}$ \\
\hline 5.6 & 4.5 & 4.1 & 5.7 & 4.8 & 4.1 & 0.6 & -3.0 & -3.9 & -4.8 & -3.1 & -6.1 \\
\hline
\end{tabular}

Source: Board of Governors of the Federal Reserve

This paper explores the economics of deleveraging and provides a simple model of the deleveraging process. The primary focus is consumer deleveraging but the economic logic also has application to firms. Consumer deleveraging affects consumer spending. Corporate deleveraging affects investment and it may also affect consumer spending via reduced dividend payments.

According to the model, deleveraging is characterized by a logic that involves a two step correction. The first step is when borrowing comes to an end. The second step is when agents start to save and re-pay debt.

Consumer deleveraging can be understood through the metaphor of a car that symbolizes the economy. Household borrowing is like stepping on the gas and accelerates economic activity as consumers spend their borrowings. When borrowing stops, the foot comes off the accelerator pedal and the car slows down. However, borrowing adds to the stock of debt, which is like a weight in the car's trunk, so that the car (i.e. economic activity) slows below its initial level. With deleveraging, households start to increase saving and re-pay debt. That is like stepping on the brake, causing the economy to slow further, akin to a double dip. Rapid deleveraging, as has happened recently, is equivalent to hitting the brakes hard. The only positive is it reduces debt, which is like removing weight from the trunk. That eventually helps restore economic activity but the process of restoration involves initial economic contraction. 


\section{Some economic preliminaries}

The model that is developed is intended to shed light on the US business cycle of the last thirty years and the predicament the US economy now finds itself in. Palley (2005 and 2008a) characterizes the period since 1980 as being marked by a new business cycle that differs dramatically from the earlier business cycle that operated from $1945-80$. This period is also often referred to as one of financialization (see Hein 20I0, Hein/van Treeck 20IO, Palley 2008b, Skott/Ryoo 2008, van Treeck 2009) during which financial markets took on a more prominent economic role. The main empirical features of financialization have been increased debt in both the household and non-financial corporate sectors; an increase in the financial sector's share of total profits; and asset price inflation.

The earlier business cycle was characterized by full employment and arrangements whereby wages grew with productivity. That established a system in which wage growth fuelled demand growth, while demand growth and full employment provided an incentive to invest. That in turn raised productivity which raised wages.

The new business cycle is marked by abandonment of full employment and severing of the wage-productivity growth link. In place of wage growth, demand growth has rested on borrowing and asset price inflation. This explains why financial deregulation and financial innovation have been important as they ensured a steady stream of products that increased borrowing capacity and raise debt ceilings.

Rising debt has been a key part of the new business cycle, but debt is a double-edged sword. Initial borrowing stimulates demand but it leaves behind a debt burden that depresses future spending (Palley 1994). This holds for both households and firms. Increased household debt entails freer spending debtor households making interest transfer payments to higher saving creditor households, which lowers demand. For firms, interest payments reduce free cash flow which lowers investment (Fazarri et al. 1988). ${ }^{1}$

\section{The model}

The model presented below has some commonalities with Bhaduri et al. (2006) who focus on the interaction between stock market wealth and debt, and the possibility of adverse medium-run growth effects of increased debt. The current model focuses on the cyclical effects of borrowing and debt. It aims to shed light on the behavior of the US economy in the era of the new business cycle, and also highlight the threat to economic recovery posed by borrower deleveraging. Both papers emphasize the significance of interest payment transfer from debtors to creditors for aggregate demand (Palley 1994).

I Palley (2004) notes that business debt interest payments can be expansionary if households' propensity to spend out of interest income exceeds the effect of reduced cash flows on business investment spending. 
The model is given by the following three equations:

$$
\begin{array}{ll}
y_{t}=[1+g]^{t} \alpha_{0}+\alpha_{1} y_{t-1}+\alpha_{2} \Delta D_{t}-\alpha_{3} i D_{t-1} & 0<\alpha_{1}<1 \\
\Delta D_{t}=\beta\left[D^{*}{ }_{t}-D_{t-1}\right] & 0<\beta<1 \\
D_{t}^{*}=[1+g]^{t} \gamma_{0}+\gamma_{1} y_{t-1} &
\end{array}
$$

$y=$ nominal output, $g=$ nominal output growth rate, $D=$ nominal debt, $\Delta D=$ nominal change in debt (borrowing or repayment), $D^{*}=$ nominal debt ceiling, subscript $t=$ current time period. This simple stylized structure is able to provide considerable insight into recent past dynamics of the US economy and the current process of deleveraging.

Equation (I) describes the evolution of output, which grows at a steady rate, $g$. Borrowing $(\Delta D>0)$ increases demand and positively impacts output, but it leaves behind a debt footprint in the form of debt service obligations that is a drag on activity $(i D)$. The coefficient $\alpha_{3}$ can be thought of as the difference in the propensity to spend of debtor and creditor units. Conversely, debt repayment $(\Delta D<0)$ negatively impacts output. This is the channel through which deleveraging operates.

Equation (2) determines borrowing and repayment. The basic logic is that of a conventional lagged adjustment mechanism in which the actual debt stock adjusts gradually to the debt ceiling. If actual debt is below the ceiling, agents borrow more, which increases activity. If actual debt is above the ceiling, agents repay debt which lowers activity. Equation (3) determines the debt ceiling which also grows at a steady rate $\mathrm{g}$ and is also affected by last period's level of output. This latter argument provides an avenue for cyclical influences on the debt ceiling.

Increases in the debt ceiling are critical to understanding business cycle developments over the past thirty years and why the US now faces a possible double dip recession. Within the model, a rising debt ceiling proxies for the processes of financial innovation and financial deregulation. The paper maintains these processes offset the underlying stagnationist tendencies of the new neoliberal business cycle created at the end of the I97os and beginning of the ig8os.

This interpretation constitutes a twist on the classic Minsky financial instability hypothesis. According to Minsky (1993) the economic system has an automatic proclivity to financial instability. Palley (2OIOa) puts a slightly different interpretation on this proclivity and argues the US has needed financial innovation and financial deregulation to maintain demand and counter stagnationist forces inherent in the neoliberal model. These developments succeeded in putting off the model's day of reckoning, but delay through increasing of debt ceilings and debt accumulation meant the ultimate crisis was more abrupt and severe when it eventually occurred.

The model given by equations (I) - (3) contains two different dynamic mechanisms. The first is a trend growth mechanism; the second is a business cycle mechanism based on debt dynamics. To enable analytical solution the paper works with the case where $g=0$ because that makes clear the role of borrowing and deleveraging which drive the business 
cycle aspect of the model, and it is this aspect which dominates the immediate economic future. Setting $g=0$ can be thought of as the analogue of examining de-trended output, borrowing, and debt.

That said, inclusion of $g$ in equations (I) and (3) provides valuable insight because it illustrates how underlying trend growth helps the economy deal with debt crises. Thus, if the economy is in an over-borrowed position $\left(D_{t}^{*}<D_{t-1}\right)$ that triggers contraction by obliging debt repayment, trend nominal output growth helps combat this impulse by raising nominal income and the debt ceiling $\left(D_{t}^{*}\right)$.

Since $g$ refers to nominal income growth, there are two ways in which over-indebtedness can undermine this stabilizing effect of trend nominal income growth. The first is if the contraction induced by over-indebtedness lowers the rate of inflation, thereby lowering trend nominal income growth and undoing this stabilizing mechanism. This possibility links directly to Fisher's (I933) debt-deflation hypothesis. The second is if over-indebtedness lowers the real rate of growth. In this regard, the existing post-Keynesian growth literature shows higher steady state debt levels can lower real growth but it can also raise real growth (Dutt 2006, Palley 20Iob).

Assuming $g=0$, steady state equilibrium involves a situation in which $D_{t}=D_{t-1}=D_{t}^{*}$ and $y_{t}=y_{t-1}=y^{*}$. Substituting these conditions in equations (I) $-(3)$ yields

$$
\begin{aligned}
& D^{*}=\gamma_{0}+\gamma_{1} y^{*} \\
& y^{*}=\left[\alpha_{0}-\alpha_{3} i \gamma_{0}\right] /\left[1-\alpha_{1}+\alpha_{3} i \gamma_{1}\right]
\end{aligned}
$$

Substituting equation (5) into equation (4) then yields

$$
D^{*}=\gamma_{0}+\gamma_{1}\left[\alpha_{0}-\alpha_{3} i \gamma_{0}\right] /\left[1-\alpha_{1}+\alpha_{3} \gamma_{1}\right]
$$

Differentiating equations (5) and (6) with respect to the exogenous parameters yields

$$
\begin{aligned}
& y^{*} / d \alpha_{0}>0, d y^{*} / d \alpha_{3}<0, d y^{*} / d i<0, d y^{*} / d \gamma_{0}<0, d y^{*} / d \alpha_{1}>0, d y^{*} / d \gamma_{1}<0, \\
& d D^{*} / d \alpha_{0}>0, d D^{*} / d \alpha_{3}<0, d D^{*} / d i<0, d D^{*} / d \gamma_{0}>0, d D^{*} / d \alpha_{1}>0, d D^{*} / d \gamma_{1}>0,
\end{aligned}
$$

Increases in autonomous spending $\left(\alpha_{0}\right)$ raise equilibrium income, in turn raising equilibrium debt. Increases in the drag from debt burdens $\left(\alpha_{3}\right)$ and the interest rate $(i)$ lower equilibrium income, which lowers equilibrium debt.

Increases in the autonomous component of the debt ceiling $\left(\gamma_{0}\right)$ and the allowable debtto-income multiple $\left(\gamma_{1}\right)$ both raise debt and lower income. The negative effect on income of higher allowable debt reflects the ultimate drag of the debt footprint.

Increases in the propensity to spend $\left(\alpha_{1}\right)$ raise equilibrium income and debt. The logic is a higher expenditure multiplier raises equilibrium income, thereby allowing more borrowing and debt.

The model given by equations (I) - (3) reduces to a two equation simultaneous system of first order difference equations given by

$$
y_{t}=\alpha_{0}+\alpha_{2} \beta \gamma_{0}+\left[\alpha_{1}+\alpha_{2} \beta \gamma_{1}\right] y_{t-1}-\left[\alpha_{2} \beta+\alpha_{3} i\right] D_{t-1}
$$




$$
D_{t}=\beta \gamma_{0}+\beta \gamma_{1} y_{t-1}+[1-\beta] D_{t-1}
$$

The necessary and sufficient stability conditions (Gandolfo 1980: 138) are

$$
\begin{array}{ll}
1-\alpha_{0}-\alpha_{2} \beta \gamma_{1}>0 & \\
\left|\begin{array}{ll}
1-\alpha_{0}-\alpha_{2} \beta \gamma_{1} & \alpha_{2} \beta+\alpha_{3} i \\
-\beta \gamma_{1} & \beta
\end{array}\right|=\beta\left[1-\alpha_{2}+\gamma_{1} \alpha_{3} i\right]
\end{array}
$$

These conditions have a familiar Keynesian interpretation. The first condition is that the partial propensity to spend $\left(\alpha_{1}+\alpha_{2} \beta \gamma_{1}\right)$ be less than unity. The second condition is that full equilibrium propensity to spend $\left(\alpha_{1}-\alpha_{3} \gamma_{1} i\right)$ be less than unity. The second condition holds if $\alpha_{1}<1$, which is the standard assumption in Keynesian models.

The first stability condition includes the parameters $\gamma_{1}$ and $\beta$. The parameter $\gamma_{1}$ affects the debt ceiling while the parameter $\beta$ affects the pace of borrowing. These parameters reflect major channels through which financialization has worked and through which it can cause instability.

Inspection of the first stability condition shows that increases in either $\beta$ or $\gamma_{1}$ increase the likelihood of instability. The logic is that increases in the magnitude of these parameters increases the size of the expenditure multiplier by adding the additional stimulus of spending financed by borrowing. Thus, if income increases, not only is there the standard marginal propensity to consume effect, there is also additional spending that comes from increased borrowing owing to a higher debt ceiling $\left(\gamma_{1}\right)$ or more rapid borrowing $(\beta)$.

Inspection of the second condition shows that increases in $\gamma_{1}$ or $i$ increase the likelihood of stability. Now, the parameter $\gamma_{1}$ operates to stabilize. Though a higher debt burden contributes to a lower equilibrium level of output, it is also stabilizing because it tamps down aggregate demand and offsets multiplier instability that may come from other sources. Thus, in response to a positive shock, a large debt burden effect means rising debt lowers aggregate demand thereby limiting opportunity for an unstable cumulative expansion of income and borrowing. Conversely, in response to a negative demand shock that causes loan repayment, a large debt burden effect means debt repayment strongly adds to aggregate demand and helps stabilize the economy.

This debt burden effect $\left(\gamma_{1} \alpha_{3} i\right)$ also points to the importance of robust counter-cycli$\mathrm{cal}$ interest rate policy which can add to debt burdens to stop expansions and reduce debt burdens to diminish contractions.

Figure I provides a stylized graphical analysis showing how output, borrowing, and debt evolve in response to an exogenous increase in the debt ceiling $\left(D_{0}^{*}<D_{1}^{*}\right)$. An increase in the debt ceiling enables agents to borrow more, which spurs aggregate demand and output. Increased output then enables additional borrowing which drives further expansion. However, as debt increases, the gap between the debt ceiling and actual debt closes, causing borrowing to gradually decline. As borrowing tapers off, the expansionary impulse weakens. 
At the same time, past borrowing raises debt that now exerts a debt drag. The strengthening debt drag and diminishing borrowing impulse then cause aggregate demand and output to fall somewhat, causing some debt repayment which further lowers output. This feature corresponds to a late-cycle pause that is characteristic of recent US cyclical expansions and it sets up conditions for a small late-cycle rebound. When the economy settles at the new equilibrium, the level of debt is higher and income is lower owing to the greater debt burden.

\section{Figure I: The evolution of output, borrowing and debt in response} to an increase in the debt ceiling $\left(D_{0}^{*}<D^{*}{ }_{1}\right)$

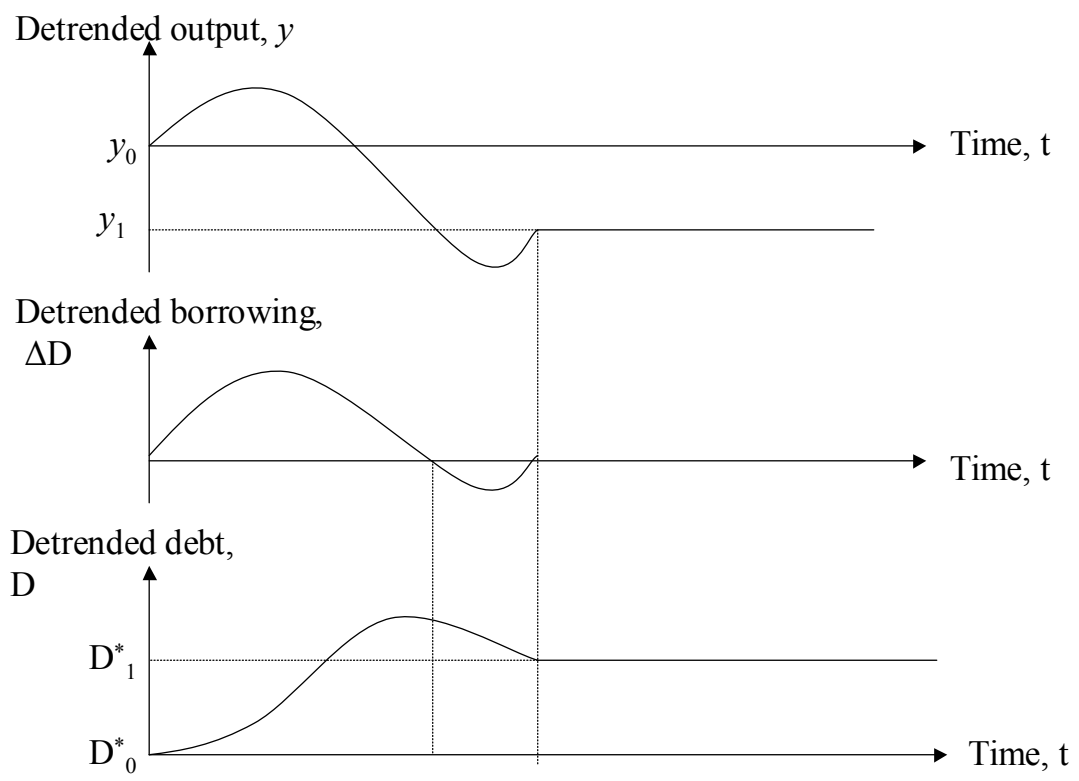

\section{Using the model to explain the neoliberal period}

The model can now be used to provide a stylized account of the US economy over the past thirty years. This involves linking developments in the real economy regarding wages and income distribution with developments in the financial sector.

\section{I The US economy, $1980-2007$}

The election of Ronald Reagan in I980 can be thought of as the official inauguration of the era of neoliberalism. The goal of neoliberalism was to increase the profit share. It did so by severing the link between wages and productivity growth. That was accomplished by abandoning commitment to full employment in favor of concern with inflation, implementing a 
new labor market flexibility agenda, and inaugurating a new era of corporate globalization. In terms of the model, the effect of lower wages and widened income inequality can be thought of as lowering aggregate demand by lowering the autonomous spending coefficient, $\alpha_{0}$.

Financial markets, through the processes of financial deregulation and innovation, then served to offset these deflationary forces. This can be thought of as increasing the parameters $\beta, \gamma_{0}$, and $\gamma_{1}$. This yields a temporary economic shot in the arm via borrowing that offsets the contractionary impact of wage stagnation and widening income inequality. However, the aggregate demand effect of wage stagnation is permanent, while the aggregate demand effect of borrowing is temporary and borrowing also leaves behind a permanent negative aggregate demand effect through higher debt. That is the contradiction of neoliberal financialization.

Financial innovation and financial deregulation increased the debt ceiling and also provided access to credit by introducing new products and increasing the spectrum of assets that could be collateralized. Examples of financial innovations include home equity loans, the spread of defined contribution pension plans that could be borrowed against, lower down-payments on mortgages, new mortgage products with initial low interest rates, and increased use of leasing arrangements.

This process is captured in Table 3 which shows the evolution of household and nonfinancial corporate debt by business cycle peak years. Having been relatively stable over the period I960 - I98I, the past thirty years have seen an explosion in household indebtedness. Non-financial corporate indebtedness also increased significantly, albeit not as fast.

\section{Table 3: Household debt / GDP and non-financial corporation debt I GDP ratios by business cycle peaks, $1960-2007$}

\begin{tabular}{|c|c|c|c|c|c|}
\hline Year & $\begin{array}{c}\text { GDP } \\
\text { (\$ billions) }\end{array}$ & $\begin{array}{l}\text { Household } \\
\text { debt }(\mathrm{H}) \\
\text { (\$ billions) }\end{array}$ & $\mathrm{H} / \mathrm{GDP}$ & $\begin{array}{c}\text { Non-financial } \\
\text { corp. debt }(\mathrm{C}) \\
\text { (\$ billions) }\end{array}$ & C/ GDP \\
\hline 1960 & 526.4 & 215.6 & $0.4 \mathrm{I}$ & 201.0 & 0.38 \\
\hline 1969 & 984.6 & 442.7 & 0.45 & 462.0 & 0.47 \\
\hline I973 & $\mathrm{I}, 382.7$ & 624.9 & 0.45 & 729.5 & 0.53 \\
\hline I98I & $3, \mathrm{I} 28.4$ & $\mathrm{I}, 507.2$ & 0.48 & I, 662.0 & 0.53 \\
\hline 1990 & $5,803 . \mathrm{I}$ & $3,597.8$ & 0.62 & $3,753.4$ & 0.65 \\
\hline $200 \mathrm{I}$ & IO,I28.O & $7,682.9$ & 0.76 & $6,954.0$ & 0.69 \\
\hline 2007 & $\mathrm{I} 3,807.5$ & $\mathrm{I} 3,765 . \mathrm{I}$ & I.OO & $10,593.7$ & 0.77 \\
\hline
\end{tabular}

Source: FRB Flow of Funds Accounts and author's calculations

Figure 2 uses the logic of the model to provide a stylized graphical history of the US economy. The I980s saw the first jump in borrowing and household debt, and that helped propel the long expansion. When it ended, both the household and non-financial corporate sector had higher debt-to-GDP ratios. 
Figure 2: A stylized history of the US economy from I98I- 2007

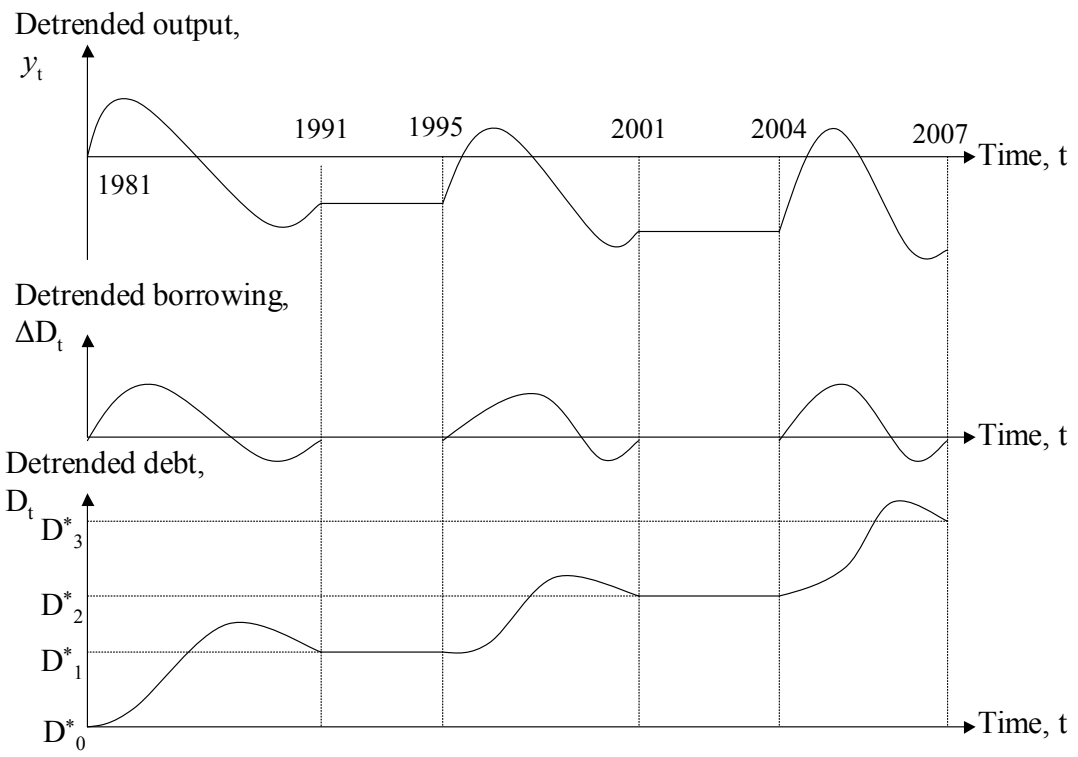

The expansion formally ended in I99I and there followed a first period of extended jobless recovery. That jobless recovery ended in 1995 when another economic boom began, spurred by a new wave of financial exuberance linked to the emergence of the Internet. The result was further increased debt combined with a stock market boom and the beginnings of a ten year house price bubble.

The Clinton era business cycle expansion ended in 200I and was followed by a second period of jobless recovery during which the Federal Reserve lowered its short-term target interest rate to the then post-World War II record low of one percent. Low interest rates plus continuing financial innovation, particularly as regards mortgage products and home equity loans, caused a further jump in debt ceilings. This enabled additional borrowing that triggered a new expansion centered on housing, which became a house price bubble that peaked in mid-2006 and imploded in summer of 2007.

The important feature of the theoretical model is that each cycle relies on borrowing to spur recovery and expansion, but the expansions die out because of higher debt burdens caused by borrowing. That burden then lowers output - in a de-trended sense $(g=0)$.

Offsetting the deflationary debt burden effect that is inherent in neoliberal financialization requires continuously increasing the debt ceiling to enable new rounds of borrowing. This new borrowing jump-starts economic expansion and buys temporary relief, but when the expansion ends the economy is saddled with yet larger debt burdens. 


\subsection{The US economy after 2007}

According to the theoretical model, when borrowing stops the economy is burdened by debt so that output is lower. This stop can be thought of as beginning the first leg of the Great Recession which was worsened enormously by the financial crisis triggered by Lehman Brothers' collapse in September 2008. The financial crisis should be thought of as an additional negative shock to output.

The second leg, which corresponds to the stage of deleveraging, began when agents started to pay back debt. In terms of the model, deleveraging is triggered by a reduction in either or both the parameters $\gamma_{0}$ and $\gamma_{1}$. That causes borrowing to turn negative, causing an additional fall in output on top of the recession shock.

The deleveraging process is the symmetric opposite of the leveraging process and it is shown in Figure 3 in which borrowing turns negative and output declines. Whereas in expansions there was an initial positive leveraging multiplier, now there is a negative deleveraging multiplier that works as follows. Debt repayment lowers aggregate demand and income, which in turn lowers allowable debt thereby forcing more debt re-payment and further demand reduction. The silver lining is loan re-payment gradually shrinks debt, thereby reducing the debt burden and setting the stage for an eventual rebound of demand and output. The big question is how long the deleveraging process goes on and how deep it is, which depends on how large is the fall in $D^{*}$ owing to the deleveraging shock. The paradox is that the deeper the deleveraging process, the greater the reduction of debt burdens, which sets the stage for future expansion. ${ }^{2}$

\subsection{Is a depression possible?}

The model provides two interpretations of a depression. One interpretation can be identified with model instability, which leads back to the necessary stability conditions discussed and the parameters $\gamma_{1}$ and $\beta$. Financialization and its accompanying financial culture can be thought of as increasing the magnitude of the parameters $\gamma_{1}$ and $\beta$, making instability more likely. Indeed, as discussed earlier, the economic logic of neoliberalism drove the system toward instability by requiring systematic on-going financial innovation and deregulation that increased the value of these parameters to offset stagnationary forces in the real economy.

The second interpretation links to the parameter $g$ that determines the trend growth of nominal output. Recall, trend growth of nominal income offsets debt burdens caused by borrowing and effectively provides an ongoing stimulant to the economy by enabling additional borrowing each period. If the deleveraging process causes $g$ to fall, this stimulant is reduced. The great danger is that $g$ turns negative, in which case it would amplify the proc-

2 Bankruptcy also reduces debt and corresponds to a form of deleveraging. Bankruptcy also leaves behind its own footprint in the form of credit stigma that reduces possibilities for future borrowing. This can be interpreted as lowering the debt ceiling $\left(\gamma_{1}\right)$. 
Figure 3: The US economy and the effect of deleveraging $\left(D^{*}{ }_{0}<D^{*}{ }_{1}\right)$

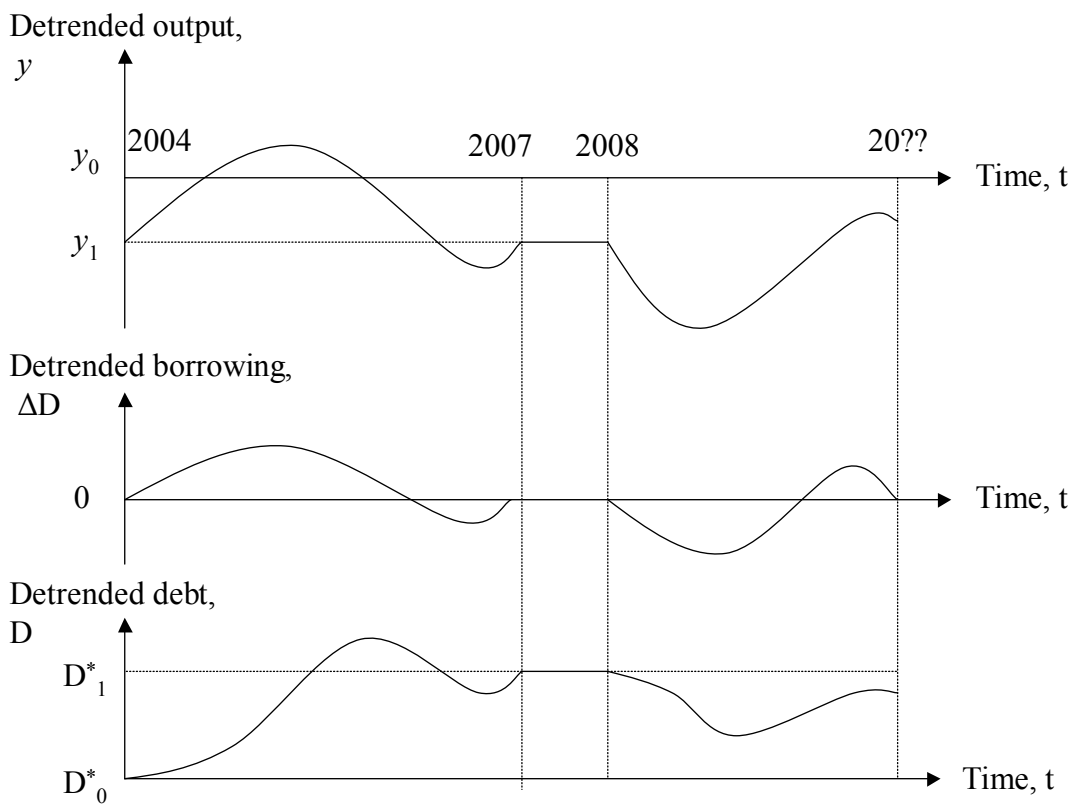

ess of deleveraging rather than mitigating it. This interpretation of depression links to the literature on Fisher's (1933) debt-deflation hypothesis (Caskey/Fazzari 1987, Palley 2008c).

If financialization has rendered the economy unstable or if deleveraging generates deflation, interest rate policy becomes critical. Upward instability can be countered by raising the central banks' short-term policy interest rate that affects the loan rate, $i$. Downward instability can be countered by lowering the short-term policy rate. This stabilizing effect of counter-cyclical interest rate policy can be seen from inspection of equation (I) in which counter-cyclical $i$ offsets pro-cyclical variation of the term $\alpha_{2} \beta \gamma_{1} y_{t-1}$. The problem in the current de-leveraging environment is that the nominal interest rate floor may block the monetary authority's ability to sufficiently lower $i$.

\section{Conclusion}

This paper has provided a simple model of deleveraging that provides significant insights into the dynamics of financialization. The model helps surface the contradictions inherent in neoliberal financialization; helps explain the pattern of the US business cycle over the past thirty years; and helps explain the depth of the current Great Recession.

Lastly, though not addressed in the body of the paper, the model is suggestive of why prolonged bond-financed fiscal deficit fiscal policy may also succumb to difficulties. Bondfinanced deficits have the government supporting aggregate demand via public borrowing 
and spending. But like the private sector, the government sector will eventually hit a debt limit, compelling fiscal retrenchment. At that stage the government will have to turn to monetizing the deficit, with consequent implications for future inflation. Alternatively, policy will have to put in place engines of demand support that do not rely on debt. That will require restoring the link between real wages and productivity growth, and replacing the business cycle model put in place in the late I970s and early I980s. Absent either of these responses, extended stagnation, that in historical retrospect may even be relabeled a depression, remains on the cards.

\section{References}

Bhaduri, A., Laski, K., Riese, M. (2006): A model of interaction between the virtual and the real economy, in: Metroeconomica, 57, 4I2-427.

Caskey, J., Fazzari, S. (1987): Aggregate demand contractions with nominal wage commitments: Is wage flexibility stabilizing?, in: Economic Inquiry, XXV, $583-597$.

Dutt, A.K. (2006): Maturity, stagnation and consumer debt: A Steindlian approach, in: Metroeconomica, $57,339-364$.

Fazzari, S., Hubbard, R.G., Petersen, B.C. (1988): Financing constraints and corporate investment activity, in: Brookings Papers on Economic Activity, I, I4I - I95.

Fisher, I. (1933): The debt-deflation theory of great depressions, in: Econometrica, I, 337 - 357.

Gandolfo, G. (1980): Economic Dynamics. Methods and Models, North-Holland: Amsterdam.

Hein, E. (20I0): A Keynesian perspective on `financialisation`, in: Arestis, P., Sawyer, M. (eds.), $2 I^{s t}$ Century Keynesian Economics, Basingstoke: Palgrave Macmillan, forthcoming.

Hein, E., van Treeck, T. (20IO): ,Financialisation ‘ in post-Keynesian models of distribution and growth - A systematic review, in: Setterfield, M. (ed.), Handbook of Alternative Theories of Economic Growth, Cheltenham: Edward Elgar, forthcoming.

Minsky, H.P. (1993): The financial instability hypothesis, The Jerome Levy Economics Institute of Bard College, Working paper No. 74, New York, 1992 and published in: Arestis, P., Sawyer, M. (eds), Handbook of Radical Political Economy, Aldershot: Edward Elgar, I53-158.

Palley, T.I (1994): Debt, AD and the business cycle: A model in the spirit of Kaldor and Minsky, in: Journal of Post Keynesian Economics, I6, 37I - 390.

Palley, T.I (2004): The simple analytics of debt - Driven business cycles, paper presented at the Post Keynesian conference, University of Missouri, Kansas City, Kansas, revised 2008.

Palley, T.I (2005): The questionable legacy of Alan Greenspan, in: Challenge, 48(6) (NovemberDecember), $17-3 \mathrm{I}$.

Palley, T.I (2008a): America's exhausted growth paradigm, in: The Chronicle of Higher Education, April II.

Palley, T.I (2008b): Financialization: what it is and why it matters, in: Hein, E., Niechoj, T., Spahn, P., Truger, A. (eds.), Finance-led Capitalism: Macroeconomic Effects of Changes in the Financial Sector, Marburg: Metropolis-Verlag, 29-6o.

Palley, T.I (2008c): Keynesian models of deflation and depression revisited, in: Journal of Economic Behavior and Organization, 68, 167-77. 
Palley, T.I (20IOa): The limits of Minsky's financial instability hypothesis as an explanation of the crisis, in: Monthly Review, 6I(II), $28-43$.

Palley, T.I (20Iob): Inside debt and economic growth: A neo-Kaleckian analysis, in: Setterfield, M. (ed), The Alternative Handbook of Growth Economics, Cheltenham: Edward Elgar, 293-208.

Skott, P., Ryoo, S. (2008): Macroeconomic implications of ,financialisation`, in: Cambridge Journal of Economics, 32(6), $827-862$.

Van Treeck, T. (2009), A synthetic stock-flow consistent macroeconomic model of , financialisation‘, in: Cambridge Journal of Economics, 33(3), 467- 493. 
